\title{
Jan Murak
}

Uniwersytet Ekonomiczny we Wrocławiu

\section{IMPERIALIZM EKONOMII}

Streszczenie: W pracy tej zostało omówione zjawisko imperializmu ekonomii jako próby unifikacji nauk społecznych do teorii ekonomii. Wskazano różnorodność proponowanych w literaturze definicji tego zjawiska i zauważono, że każda z nich w jakimś stopniu podkreśla przekraczanie tradycyjnych granic ekonomii. Często wskazuje się także agresywny charakter tego procesu. Następnie omówiono czynniki sprzyjające rozwojowi imperializmu ekonomii, wśród których można wyróżnić: definicję ekonomii według L.C. Robbinsa, definicje innych nauk społecznych czy też czynniki polityczne. Najważniejsza jednak była idea unifikacji nauki, jako jeden z najbardziej „czystych” celów naukowego teoretyzowania według wielu badaczy. Oddziaływanie tego ostatniego czynnika było wzmocnione także przez niepowodzenie w znalezieniu mikropodstaw makroekonomii, czyli wewnętrznej unifikacji ekonomii - przedstawiciele głównego nurtu, poszukując potwierdzenia swojej przewagi nad szkołami heterodoksyjnymi, zaczęli - z wykorzystaniem narzędzi, założeń i metod dla nich charakterystycznych - badać różne, nierynkowe sfery aktywności ludzkiej. W dalszej części wyróżniono dwa kryteria podziału imperializmu ekonomii. Pierwsze kryterium dotyczy przedmiotu badania czy też innymi słowy poziomu analizy, w związku z tym wyróżnia się imperializm w głąb i imperializm na zewnątrz ekonomii. Ten pierwszy ma na celu odejście od tradycyjnych podmiotów gospodarczych i analizę tego, z czego składają się te podmioty i jak one funkcjonują, natomiast imperializm na zewnątrz bada zjawiska związane z podejmowaniem przez podmioty gospodarcze decyzji, które nie są powiązane w sposób bezpośredni z formalnymi rynkami. Drugie kryterium dotyczy użytej metodologii; wyróżnia się na jego podstawie stary oraz nowy imperializm. Stary imperializm, którego nazwa wynika z faktu, że został zapoczątkowany wcześniej, jednak w dalszym ciągu prowadzone są tego rodzaju badania, wykorzystuje podejście metodologiczne ekonomii neoklasycznej, z takimi pojęciami i założeniami jak stałość preferencji, efektywność czy równowaga rynkowa. Dlatego też każdy obszar życia człowieka jest traktowany jak gdyby dotyczył on formalnych rynków. Głównym przedstawicielem starego imperializmu jest G.S. Becker, który analizował w taki sposób m.in. prawo. Natomiast nowy imperializm ekonomii związany jest z nową ekonomią instytucjonalną i jej podejściem metodologicznym. W związku z tym różne zachowania ludzi są traktowane jako reakcje na niedoskonałości rynkowe, a głównym orędownikiem takiego podejścia jest B. Fine. W końcowej części pracy wskazano, że pomimo pewnych sukcesów imperializmu ekonomii, związanych ze spostrzeżeniem wcześniej nieodkrytych zależności lub wyjaśnieniem pewnych zachowań ludzi, spotyka się on z krytyką. Dotyczy ona przede wszystkim niespełnienia przesłanek uzasadnionej unifikacji nauki, zgodnie z którymi, po pierwsze, nowa zunifikowana teoria powinna wyjaśniać wszystkie problemy, wytłumaczone przez wcześniejsze teorie, a po drugie, omawiane przez tę teorię zjawiska powinny wynikać z oddziaływania na nie tych samych realnych czynni- 
ków. Dlatego też ocena zjawiska imperializmu ekonomii nie jest jednoznaczna, niemniej jednak można oczekiwać w przyszłości kontynuacji procesu konkurencji ekonomii z innymi dziedzinami nauki na ich polach badawczych.

Słowa kluczowe: imperializm ekonomii, teoria ekonomii, nauki społeczne, metodologia ekonomii, unifikacja nauki.

DOI:10.15611/e21.2014.3.08

\section{Wstęp}

Przez wielu autorów ekonomia, utożsamiana z jej głównym nurtem, jest uważana za posiadającą najlepsze narzędzia i metody badawcze ze wszystkich nauk społecznych. Jej oparty na matematyce formalizm pozwala lepiej, bardziej systematycznie opisywać, kategoryzować, a nawet przewidywać rzeczywistość. O sukcesie ekonomii mają świadczyć takie zjawiska, jak: duża popularność tego kierunku wśród studentów czy szczególne zainteresowanie dziennikarzy, polityków i naukowców tematami gospodarczymi. Jednak w tym samym czasie ekonomia spotyka się z silną krytyką, często tych samych, dziennikarzy, polityków i naukowców. Krytyka ta dotyczy nieodpowiedniości narzędzi i metod ekonomii do opisu rzeczywistości gospodarczej. Jej przedstawicielom jest zarzucane, że chociaż od wydania $O$ naturze i przyczynach bogactwa narodów A. Smitha minęło już ponad 230 lat, nie są w stanie przewidzieć kryzysów gospodarczych, chociażby ostatniego kryzysu finansowego, a nawet nie są w stanie jednoznacznie stwierdzić, co do nich doprowadziło, np. do dnia dzisiejszego trwają dyskusje na temat głównych przyczyn wielkiego kryzysu lat 1929-1933.

Tym dwóm punktom widzenia towarzyszą dwa zjawiska. Z jednej strony zwolennicy ekonomii starają się „najeżdżać” inne nauki społeczne, tzn. za pomocą narzędzi i metod badawczych charakterystycznych dla ekonomii wyjaśniać zjawiska, które w tradycyjnym podziale były obszarem zainteresowania m.in. socjologii, politologii, prawa czy psychologii. Oznacza to, że ekonomia konkuruje z tymi naukami na ich polach badawczych i według wielu autorów, przede wszystkim przedstawicieli głównego nurtu, czyni to bardzo skutecznie. Z drugiej strony mamy naukowców, którzy dostrzegają słabości ekonomii. Przyczynia się to do poszukiwania przez nich nowych koncepcji czy też zapożyczania ich z innych dyscyplin. To z kolei prowadzi do kooperacji ekonomistów z przedstawicielami innych nauk społecznych, ale także przyrodniczych, co skutkuje między innymi tym, że współcześnie badaniem zjawisk gospodarczych w sposób naukowy zajmują się także nieekonomiści.

Celem niniejszej pracy jest opis zjawiska imperializmu ekonomii, znalezienie głównych przyczyn jego wystąpienia, cech charakterystycznych oraz kategoryzacja. Pozwoli to na lepsze zrozumienie zmian, jakie zachodzą we współczesnej ekonomii. Praca ta także, chociażby w pewnym stopniu, umożliwi ocenę tego zjawiska, a przez to pozwoli postawić przypuszczenia co do przyszłości ekonomii jako nauki. Celowi 
badawczemu pracy podporządkowano strukturę artykułu. W następnym rozdziale przedstawiono dyskusje wokół samej nazwy tego zjawiska oraz jego definicji, co przyczyniło się do wyodrębnienia cech szczególnych oraz podziału. W kolejnej części omówiono główne czynniki, które sprzyjały imperializmowi ekonomii. Następnie przedstawiono metodologię imperializmu ekonomii, która pozwoliła jej przedstawicielom na analizę zjawisk niebędących w tradycyjnym obszarze zainteresowania ekonomii. Na zakończenie przedstawiono krytykę ,podejścia imperialistycznego”.

\section{Spór wokól definicji}

Rozważania na temat imperializmu ekonomii należy rozpocząć od spostrzeżenia, że istnieją poważne problemy związane $\mathrm{z}$ samą nazwą tego zjawiska. W literaturze ekonomicznej można się spotkać z wieloma terminami, lecz dwa, a mianowicie imperializm ekonomiczny i imperializm ekonomii, są najczęściej używane. Imperializm ekonomiczny jest terminem preferowanym przede wszystkim przez przedstawicieli głównego nurtu, m.in. Lazeara, autora szeroko omawianej pracy na temat tego zjawiska [Lazear 2000]. Pojęcie to jest także chronologicznie starsze, gdyż, jak pisze Hodgson [2001, s. 198-199], po raz pierwszy zostało użyte w kontekście omawianego procesu przez Soutera w 1930 roku. Fine i Milonakis [2009, s. 10] upatrują przyczyny wyboru tego terminu przez ekonomistów ortodoksyjnych w całkowitym pominięciu przez nich drugiego znaczenia imperializmu ekonomicznego, a mianowicie - w realnej gospodarce tym terminem nazywa się proces gospodarczego wyzysku kolonii i krajów rozwijających się przez wielkie imperialne mocarstwa. Po raz pierwszy zwrot ten został użyty w tym znaczeniu przez Lenina i Hobsona, jednak także współcześnie jest on stosowany w takim kontekście, czego przykładem może być dość niedawno wydana książka pod tytułem Chiny światowym hegemonem? Imperializm ekonomiczny Państwa Środka [Brunet, Guichard 2011]. W związku z tym, w celu uniknięcia podwójnego znaczenia, wspomniany Fine, ale także między innymi Mäki - są zwolennikami terminu imperializm ekonomii. Ponadto część ekonomistów proponuje inne nazwy tego zjawiska, odrzucając słowo imperializm. Olson i Kähkönen [2000] twierdzą, że przekraczaniu granic przez ekonomię nie towarzyszy użycie siły, a w związku z tym proponują metaforę ekonomii jako metropolii rozszerzającej swoje wpływy na podmiejskie nauki społeczne. Ostrom preferuje z kolei określenie „potlacz ${ }^{1}$ raczej niż jakiś imperializm” [Ostrom 2007, s. 240]. Jednak należy zauważyć, że termin potlacz odnosi się raczej do kooperacji, a nie do konkurencji.

$\mathrm{W}$ tej pracy preferowany jest termin imperializm ekonomii. Przemawiają za tym dwie przesłanki. Po pierwsze, jak już zostało napisane, określenie imperializm ekonomiczny odnosi się do dwóch zjawisk, przez co jest ono niejednoznaczne. Po drugie, w jedynym polskim artykule ekonomicznym, jaki został opublikowany na

${ }^{1}$ Potlacz - święto wymiany darów u Indian północnoamerykańskich. 
ten temat [Brzeziński i in. 2009], preferowany jest właśnie termin imperializm ekonomii. W związku z tym jedynie w miejscu cytatów bezpośrednich lub pośrednich pojawi się termin imperializm ekonomiczny.

Pomimo wielości użytych określeń wszystkie te terminy odnoszą się do jednego zjawiska. Należy jednak rozpocząć, jak sugeruje Mäki, od zdefiniowania szerszego pojęcia, jakim jest ekspansja ekonomii. Tym terminem określa on ,proces stałego dążenia do wzrostu stopnia unifikacji, dostarczanej przez teorię ekonomii, poprzez stosowanie jej do zjawisk nowego typu" [Brzeziński i in. 2009, s. 53]. Natomiast „,imperializm ekonomii jest formą ekspansjonizmu ekonomii, w której nowe typy wyjaśnianych zjawisk należą do terytoriów okupowanych przez dyscypliny inne niż ekonomia" [Brzeziński i in. 2009, s. 54]. Oznacza to, że istnieją także nieimperialistyczne formy ekspansji ekonomii, czyli takie „które zajmują się zjawiskami poprzednio niebędącymi w kręgu zainteresowań ani ekonomii, ani innych nauk" [Brzeziński i in. 2009, s. 53]. Tę definicję imperializmu ekonomii można nazwać szeroką, gdyż w dalszej części swojej pracy Mäki proponuje inną, w której podkreśla stosunek ekonomii do innych nauk społecznych, pisząc, że ,imperializm ekonomii jest formą ekspansjonizmu ekonomii, w której nowe typy wyjaśnianych zjawisk należą do terytoriów okupowanych przez dyscypliny inne niż ekonomia i gdzie ekonomia stawia siebie w pozycji hegemonicznej, posiadającej lepsze teorie i metody, a tym samym wyłączając teorie i podejścia rywali z rozważań" [Mäki 2007, s. 24]. Brzeziński, Gorynia i Hockuba podkreślają zaś w swojej definicji jej agresywny charakter, pisząc: „Imperializm ekonomii jest zatem świadomie, uparcie i agresywnie prowadzonym procesem przekraczania granic przedmiotu ekonomii jako nauki, w wyniku którego przedmiot ten uległ rozszerzeniu o te nowe typy zjawisk (zdarzeń i procesów), które tradycyjnie lub zgodnie z konwencją historyczną nie należały do przedmiotu zainteresowań ekonomistów, a były badane przez przedstawicieli innych nauk społecznych" [Brzeziński i in. 2009, s. 53].

Inne podejście prezentuje Lazear, który w swojej definicji wymienia części składowe tradycyjnej ekonomii, a także podkreśla, że zjawisko imperializmu ekonomii zachodzi w dwóch kierunkach: na zewnątrz i w głąb ekonomii - „Ekonomiczny imperializm jest zdefiniowany jako rozszerzenie ekonomii na tematy będące poza tradycyjnym zakresem zagadnień, takim jak wybór konsumenta, teoria przedsiębiorstw, rynki (formalne), makroekonomia i zjawiska związane bezpośrednio z nimi. Najbardziej agresywni przedstawiciele ekonomicznego imperializmu mają za cel wyjaśnienie wszystkich zachowań społecznych poprzez użycie narzędzi ekonomicznych. Zjawiska uznawane tradycyjnie za niebędące przedmiotem badawczym ekonomii, ponieważ nie są związane z formalnymi rynkami i cenami, są analizowane przez przedstawicieli imperializmu ekonomicznego. [...] Ponadto te problemy, które leżą na głębszym poziomie [analizy] niż ten w tradycyjnej ekonomii, są także częścią imperializmu ekonomicznego" [Lazear 2000, s. 6-7]. Poprzez imperializm ekonomii w głąb rozumie Lazear przejście na inny, głębszy poziom abstrakcji niż ten związany $\mathrm{z}$ takimi pojęciami, jak gospodarstwo domowe i przedsiębiorstwo, na poziom, na 
którym rozważane są preferencje, skład gospodarstw domowych czy funkcjonowanie firm. Pozostałe obszary badawcze imperializmu ekonomii należy rozumieć jako przykłady zewnętrznego kierunku ekspansji na inne nauki społeczne.

Fine wyróżnia w swoich pracach dwa rodzaje, czy też etapy, imperializmu ekonomii: stary i nowy. Podział ten związany jest jednak przede wszystkim z wykorzystywanymi przez nie podejściami metodologicznymi. Stary imperializm ekonomii jest, według tego autora, utożsamiany przede wszystkim z Beckerem i jego podejściem ekonomicznym, czyli traktowaniem każdej sfery życia tak, jakby funkcjonowały one na zasadach rynkowych, a rynki te byłyby doskonale konkurencyjne lub im bardzo bliskie. Ta faza imperializmu przeważała od lat 30. do 80. XX wieku. Natomiast nowy imperializm ekonomii, którego intensywny rozwój był możliwy dopiero od lat 70. XX wieku, kiedy to, głównie dzięki pracy Akerlofa [1970], zaczęto dokładniej analizować problemy dotyczące informacji, jest związany między innymi z Stiglitzem i nową ekonomią instytucjonalną. Dokładniej różnica w metodologii pomiędzy tymi fazami będzie przedstawiona $w$ kolejnym rozdziale, $w$ tym miejscu warto jednak zacytować Fine’a, który pisze: „W skrócie, stary styl imperializmu ekonomii starał się rozszerzyć granice ekonomicznego podejścia, żeby włączyć problemy badawcze innych nauk społecznych. Natomiast nowy styl rozpoznał te granice poprzez rozszerzenie własnych metod, żeby je zarówno przekroczyć, jak i w pewnym sensie uszanować" [Fine, Milonakis 2009, s. 74]. Jednak jak sam zauważa [Fine 2000, s. 16], wyolbrzymianie różnic pomiędzy tymi fazami jest bezpodstawne, gdyż obie opierają się na wielu podobnych założeniach. Ponadto zarówno stary jak i nowy imperializm są ,winne" redukcjonizmowi: ten pierwszy analizuje wszystkie zjawiska społeczne ,jak gdyby" występowały one na formalnych rynkach, natomiast drugi bada zarówno gospodarkę, jak i inne zjawiska społeczne, ,jak gdyby" były odpowiedzią na rynkowe niedoskonałości. Jako pewnego rodzaju ciekawostkę można podać, że część badaczy, m.in. Fine [2000] czy też Levitt i Dubner [2011a, 2011b], wyróżnia, jako kolejny etap imperializmu ekonomii, freakonomię (freakonomics), którą można nazwać „ekonomią wszystkiego”.

Tabela 1. Kryteria podziału imperializmu ekonomii wraz z przykładami

\begin{tabular}{|l|l|l|}
\hline Imperializm ekonomii & \multicolumn{1}{|c|}{ Stary } & \multicolumn{1}{|c|}{ Nowy } \\
\hline W głąb & $\begin{array}{l}\text { teoria alokacji czynnika czasu G. } \\
\text { Beckera - „wewnętrzna” funkcja } \\
\text { produkcji gospodarstw domowych }\end{array}$ & $\begin{array}{l}\text { teoria kosztów transakcyjnych - } \\
\text { wyjaśnienie powstania } \\
\text { i funkcjonowania przedsiębiorstw }\end{array}$ \\
\hline Na zewnątrz & $\begin{array}{l}\text { podejście ekonomiczne do prawa } \\
\text { G. Beckera }\end{array}$ & $\begin{array}{l}\text { nowa ekonomia polityczna }- \text { głównie } \\
\text { szkoła z Wirginii }\end{array}$ \\
\hline
\end{tabular}

Źródło: opracowanie własne.

Podsumowując powyższe rozważania na temat definicji imperializmu ekonomii, należy zauważyć, że pomimo ich wielości wszystkie podkreślają, że jest to zjawisko polegające na przekraczaniu tradycyjnych granic ekonomii i najlepiej w opinii 
autora odpowiada charakterowi tego zjawiska definicja zaproponowana przez Brzezińskiego, Gorynię i Hockubę. Ponadto można wyróżnić dwa kryteria podziału imperializmu ekonomii. Pierwszy ze względu na kierunek analizy, a drugi ze względu na metodologię. Schematycznie, wraz z przykładami, podział ten przedstawia tab. 1.

\section{Czynniki sprzyjające imperializmowi}

Warto także zastanowić się nad czynnikami sprzyjającymi imperializmowi ekonomii. Przede wszystkim zjawisko to było możliwe dzięki wyróżnieniu ekonomii nie poprzez przedmiot, a poprzez metodę badania zgodnie $\mathrm{z}$ definicją ekonomii Robbinsa, mówiącą, że ,jest to nauka, badająca postępowanie ludzkie jako ustosunkowanie między celami a ograniczonymi środkami, zdatnymi do alternatywnych użytków" [Taylor 2004, s. 29]. W związku z nią ekonomia jest nauką o racjonalnym wyborze, a to oznacza, że może być wykorzystana nie tylko w odniesieniu do formalnych rynków, ale także w analizie innych zachowań społecznych, takich jak rodzicielstwo, dyskryminacja czy polityka. Taki tok rozumowania przedstawia m.in. Medema, która pisze: „Ekonomia bada wybór, a wszystkie [sfery] życia powiązane są z podejmowaniem wyborów; czy ekonomia w takim razie nie powinna mieć zastosowania do wszystkich rodzajów ludzkich decyzji i zatem do wszystkich sfer ludzkiego życia?" [Fine, Milonakis 2009, s. 12], czy Hirschleifer, twierdząc, że „racjonalne, egoistyczne wybory odnoszą się do wielu innych dziedzin życia niż rynek, na przykład do polityki, wojen, wyboru przyjaciół, projektów technicznych i statystycznych decyzji”, [Hirshleifer 1985, s. 53].

Drugim czynnikiem sprzyjającym temu zjawisku, przywoływanym przez Beckera [1990, s. 21], jest brak precyzyjnego określenia definicji, przedmiotu badań i sposobów podejścia innych nauk społecznych. Jak zauważa ten autor, definicje socjologii, która ,polega na badaniu społecznych zbiorowości i grup z punktu widzenia ich organizacji instytucjonalnej, a także instytucji i ich organizacji oraz przyczyn i skutków zmian zachodzących w instytucjach i sposobach organizacji społeczeństwa” [Becker 1990, s. 21], ani psychologii porównawczej, która „zajmuję się zachowaniami różnych gatunków organizmów żyjących" [Becker 1990, s. 21], nie dostarczają charakterystycznych cech tych dyscyplin, pozwalających jasno określić granice, przez co pośrednio umożliwiają imperializm ekonomii.

Trzecią przyczyną jest występująca w naukach, a zwłaszcza w naukach przyrodniczych, chęć unifikacji, czyli dążenie do jedności nauki. Przez to pojęcie należy rozumieć dążenie do wyjaśnienia jak największej liczby zjawisk poprzez jak najmniejszą liczbę podstawowych założeń czy twierdzeń czy też, zgodnie z Mäkim, „maksymalizowanie liczby wniosków naukowych przy minimalnej liczbie schematów wyjaśniających” [Brzeziński i in. 2009, s. 56], „,redukowanie liczby pozornie oddzielnych i różnych zjawisk poprzez pokazanie, że są one manifestacją tego samego systemu" [Brzeziński i in. 2009, s. 56]. Unifikacja jest powszechnie uznawana za jeden z najmniej kontrowersyjnych i najbardziej „czystych” celów naukowego 
teoretyzowania - „Ogólna zasada sugeruje, że odnosząca sukcesy imperialistyczna teoria ekonomii z większym prawdopodobieństwem jest prawdziwa aniżeli te bez takich sukcesów" [Mäki 2007, s. 12]. Przedstawia autor ten także ogólne przesłanki warunkujące, czy proces unifikacji jest uzasadniony [Mäki 2007, s. 12]:

- Po pierwsze, zunifikowana teoria musi wyjaśniać jedynie te różne zjawiska, które są wynikiem oddziaływania na nie tych samych realnych czynników.

- Po drugie, nowa zunifikowana teoria musi wyjaśniać wszystkie lub prawie wszystkie zjawiska wyjaśniane dotychczas przez pojedyncze teorie, które zostały zunifikowane.

Związany z ekonomią proces unifikacji, trwający od ponad 70 lat, można podzielić na dwa etapy. Pierwszy z nich to proces wewnętrznej unifikacji ekonomii, a drugi, właściwy imperializmowi ekonomii, proces unifikacji rozumiany jako redukcja pozostałych nauk społecznych do ekonomii. Wewnętrzna unifikacja ekonomii miała miejsce pomiędzy 1940 a 1980 rokiem, a była prowadzona przede wszystkim przez przedstawicieli skupionych wokół głównego nurtu. W jej ramach starano się stworzyć jedną, spójną teorię ekonomii odnosząca się do wszystkich sfer życia gospodarczego, przez co w szczególności dążono do zbudowania mikropodstaw dla makroekonomii. Miała być ona oparta na neowalrasowskiej teorii równowagi ogólnej, dzięki czemu całość teorii byłaby zbudowana na kilku podstawowych założeniach ekonomii neoklasycznej - pełna racjonalność, stabilność preferencji i równowaga rynków. Pomimo że nie udało się w pełni zrealizować wewnętrznej unifikacji, a może właśnie dlatego (o czym poniżej), następował, po części równolegle, proces zewnętrznej unifikacji, związany z imperializmem ekonomii, w którym dążono do stworzenia jednej nauki społecznej opartej na ekonomii.

Odwołując się do unifikacji nauk społecznych, warto wspomnieć, że podobny cel rozwoju własnej nauki wyznaczało sobie kilku znakomitych socjologów. Takie poglądy prezentował między innymi Comte, który uważał, że ekonomia powinna być wyspecjalizowaną częścią tej nauki, gdyż zjawiska gospodarcze stanowią część zjawisk społecznych, którymi zajmuje się socjologia. Do tego stanowiska odwoływał się oraz zgadzał się z nim włoski ekonomista i socjolog Pareto. Również u Marksa można się doszukać myśli, że ekonomia to swoista socjologia życia gospodarczego.

Kolejnej przyczyny wystąpienia „postawy imperialistycznej” można upatrywać, o czym już wspomniano, właśnie w niepowodzeniu wewnętrznej unifikacji i rywalizacji pomiędzy nurtami w ramach ekonomii. Na skutek niemożności stworzenia jednej teorii ekonomii przedstawiciele głównego nurtu zaczęli poszukiwać innych dowodów przewagi własnej teorii nad teoriami szkół heterodoksyjnych. W związku z tym rozpoczęli poszukiwanie empirycznych dowodów poprawności swoich założeń i formalnych modeli w sferach życia społecznego innych niż gospodarka. Warto w tym miejscu zauważyć, że początkowo podejście Beckera i innych przedstawicieli imperializmu spotykało się z większą niechęcią wśród przedstawicieli ekonomii aniżeli przedstawicieli „podbijanych” nauk, m.in. socjologów. Jak sam Becker wspomina: „Przez długi czas [...] większość czołowych ekonomistów albo moją 
pracę ignorowała, albo traktowała ją z dużą niechęcią. Uważano mnie za outsidera i prawdopodobnie nie do końca ekonomistę" [Levitt, Dubner 2011b, s. 27].

Ostatnim czynnikiem wspierającym imperializm ekonomii, szczególnie w formie teorii wyboru publicznego i teorii wyboru społecznego, przywołanym przez Amadeę [2003], są implikacje polityczne i ideologiczne tych teorii. Autorka ta twierdzi, że neoklasyczne teorie silnie wspierają doktrynę ideologiczną liberalizmu, opartą na wolnych rynkach i wolności racjonalnej jednostki. W związku z tym kierunek ten odegrał znaczącą rolę w starciu ideologii komunistycznej i liberalnej w drugiej połowie XX wieku i w ostatecznym zwycięstwie tej ostatniej.

Podsumowując, można zauważyć, że dopiero mieszanka wszystkich powyższych czynników, czyli związanych z definicją ekonomii i innych nauk społecznych, unifikacją, historią, wewnętrzną rywalizacją i ideologią, umożliwiła powstanie i rozwój imperializmu ekonomii. Każdy z tych czynników odegrał ważną rolę, ale pozostawiony osobno nie doprowadziłby do imperializmu ekonomii.

\section{Metodologia nowego i starego imperializmu}

W tym rozdziale zostanie przedstawiona metodologia wykorzystywana w imperializmie ekonomii, w podziale na jej stary i nowy etap. Przy opisie będzie zwrócona przede wszystkim uwaga na występujące między nimi różnice. Metodologię używaną przez stary imperializm ekonomii najwłaściwiej jest utożsamiać z podejściem zaproponowanym przez Beckera, które opiera się na aksjomatach ekonomii neoklasycznej. Autor ten podkreśla trzy podstawowe założenia: maksymalizujący charakter zachowań, rynkową równowagę i stałość preferencji. „Bezwzględne i konsekwentne posługiwanie się kombinacją tych założeń [...] stanowi istotę podejścia ekonomicznego w moim rozumieniu" [Becker 1990, s. 23].

Poprzez maksymalizujący charakter zachowań Becker rozumie racjonalność zarówno podmiotu, jak i jego dążenia do maksymalizacji użyteczności. Ekonomista ten (ale również Lazear) sprowadza te założenie do twierdzenia, że człowiek nie działa bezcelowo, wie co robi i dlaczego to robi, chociaż nie musi być w pełni świadom własnych dążeń maksymalizujących. Nie posiada on pełnej informacji, ale jest w stanie określić, do jakiego momentu opłaca mu się uzupełniać wiedzę. Ponadto jego zasoby są ograniczone. Prowadzi to podmiot do uszeregowania celów według ich użyteczności i do realizacji tych, które przy ograniczonych środkach ją maksymalizują. Oznacza to, że w każdym aspekcie życia człowiek spotyka się z problemem optymalizacji i nie ma tutaj znaczenia „ważność” i emocjonalność podejmowanych decyzji - czy chodzi o te związane z ,życiem lub śmiercią", czy też o wybór gumy do żucia, jak pisze Becker. Odnosząc się do poglądu Benthama, zgodnie z którym nawet „namiętność kalkuluje”, zauważa dalej: „A więc rachunek przyjemności i przykrości ma mieć zastosowanie do wszystkiego, co robimy, mówimy i myślimy, nie ograniczając się wcale do decyzji przeliczalnych na pieniądz, wyborów powtarzających się, decyzji mniej ważnych itp." [Becker 1990, s. 28]. Lazear zarzuca innym naukom społecznym, że nie zauważają ,napięcia” występującego pomiędzy kosztami a korzyściami, przez 
co są one ograniczone w swoich analizach. Podmiot maksymalizujący, w podejściu prezentowanym przez stary imperializm, jest egoistą, jednak nie w „tradycyjnym” tego słowa znaczeniu. Zdaje on sobie sprawę z istnienia zależności pomiędzy dobrobytem innych, zazwyczaj bliskich mu osób, a jego stanem zadowolenia. W związku z tym może poświęcić część własnej konsumpcji na rzecz innych osób - czyni to jednak w dalszym ciągu w celu maksymalizacji własnej użyteczności. Dlatego też niemal wszelkiego rodzaju zachowania altruistyczne mogą być analizowane poprzez koncepcję maksymalizacji użyteczności. Problem ten w sposób szczególny jest rozważany w eseju Beckera pod tytułem Altruizm, egoizm i przystosowanie genetyczne: teoria ekonomii a socjologia [Becker 1990, s. 488-511].

Drugim założeniem podejścia prezentowanego przez Beckera i związanym ze starym imperializmem ekonomii jest istnienie równowagi rynkowej. Hipoteza ta składa się z trzech części: po pierwsze, w każdej sferze życia występują albo formalne rynki albo rynki cienie, po drugie, na rynkach tych istnieją pieniężne ceny lub ceny cienie, a po trzecie, wszystkie rynki dążą do równowagi. Formalne rynki stanowią główny obszar zainteresowania ekonomii od początków wyodrębnienia się jej jako nauki, jednak pojęcie rynków cieni jest novum związanym bezpośrednio $\mathrm{z}$ imperializmem ekonomii w jej starym stylu i odnosi się do wszystkiego rodzaju nieformalnych rynków. Przykładem rynku cienia może być rynek małżeński (doboru partnerów), rynek potomstwa czy rynek przestępstw. Na rynkach tych, podobnie jak na rynkach formalnych, następuje porównanie ofert $\mathrm{z}$ własnymi oczekiwaniami, które mogą się zmieniać. Jeżeli oczekiwania i oferty są zgodne, dochodzi do transakcji. Tak szeroko rozumiane rynki Hagemejerowa zdefiniowała jako „miejsce konfrontacji, z jednej strony, życzeń (potrzeb, aspiracji) $n$ uczestników, a z drugiej, oferty tego, co ci uczestnicy w takim lub innym sensie mają na zbyciu, czy tego, z czego są oni skłonni zrezygnować za coś innego" [Becker 1990, s. 11]. Charakterystyczną cechą rynków cieni jest niewystępowanie na nich pieniężnych cen; ich miejsce zajmują ceny cienie, które także są wynikiem oddziaływania na siebie popytu i podaży. Według Beckera ceny cienie są „miarą »kosztu zaniechanych możliwości« (opportunity cost) związanego z użyciem rzadkich zasobów" [Becker 1990, s. 24]. Warto zauważyć, że pojęcie cen cieni czy też cen kalkulacyjnych nie jest związane jedynie $\mathrm{z}$ imperializmem ekonomii, ale także m.in. z cybernetyką.

Najważniejszą jednak cechą rynków, umożliwiającą tak daleko posunięte wnioski, jakie często są wysuwane w ramach ekspansji ekonomii na inne nauk społeczne, jest ich dążenie do równowagi. Jak pisze Lazear, to właśnie zainteresowanie tym pojęciem wyróżnia ekonomie od innych nauk społecznych [Lazear 2000, s. 4]. Zauważa także, że „prawie wszystkie teorie ekonomiczne wysuwają podstawowe żądanie, że opisane zachowanie musi być zgodne z jakąś formą pojęcia równowagi" [Lazear 2000, s. 3]. Zarzuca ponadto innym naukom społecznym, że nie wykorzystują tego pojęcia, gdyż uważają, że osiągnięcie równowagi zajmuje zbyt dużo czasu i zbyt wiele się zmieni, zanim dana równowaga zostanie osiągnięta. Pojęciem związanym $\mathrm{z}$ równowagą, a przedstawianym przez Lazeara jako trzecie podstawowe pojęcie imperializmu ekonomii, jest efektywność. Zauważa on, że wykorzystywanie koncepcji 
równowagi oraz efektywności zapobiega formułowaniu przez ekonomistów częściowych odpowiedzi lub półprawd. Warto podkreślić, że analizy przeprowadzane przez Beckera oparte są bardzo często na najbardziej efektywnym (minimalizującym martwą rentę) rodzaju rynku, czyli konkurencję doskonałą.

Trzecim założeniem przyjmowanym przez Beckera jest stałość preferencji. Jest to chyba najbardziej kontrowersyjna $\mathrm{z}$ hipotez starego imperializmu, dlatego nawet jego zwolennik, którym jest niewątpliwie Lazear, przemilczał ją w swoim artykule. Jest to bardzo użyteczne założenie, dzięki któremu możliwe są daleko posunięte wnioski, pozwalające m.in. na prognozy zachowań podmiotów znajdujących się w nowej sytuacji. Jednak wiele badań pokazuje błędność tej hipotezy. Warto w związku z tym dokładniej przyjrzeć się samemu temu założeniu w rozumieniu Beckera, jak i jego uzasadnieniu. Według tego autora, stałe preferencje podmiotów nie odnoszą się do wyboru pomiędzy takimi dobrami, jak jabłko czy gruszka, ale przede wszystkim do podstawowych wartości przyjmowanych przez te podmioty, które są ,produkowane” z użyciem dóbr rynkowych, czasu i innych nakładów. Preferencje te dotyczą najbardziej podstawowych „,aspektów życia, takich jak zdrowie, prestiż, zadowolenie, życzliwość lub zawiść, bynajmniej nie zawsze pozostających w stałym stosunku do rynkowych dóbr i usług" [Becker 1990, s. 23]. Jak dalej pisze Becker, założenie stałości preferencji chroni badaczy przed tłumaczeniem rozbieżności pomiędzy prognozą a realnym stanem poprzez zmianę preferencji podmiotów. Takie tłumaczenie jest, według niego, w wielu przypadkach zbyt proste, gdyż same preferencje są trudno obserwowalne i weryfikowalne. Preferencje są wynikiem ewolucyjnych zmian; oznacza to w opinii Beckera, że w zasadzie są one zmienne $\mathrm{w}$ czasie, ale jedynie dla bardzo długiego horyzontu czasowego. W związku z tym na potrzeby analizy ekonomicznej czy też społecznej można przyjąć, że są one stałe. Ponadto różne grupy społeczne posiadają bardzo podobne czy wręcz takie same preferencje - „nie ma zasadniczych różnic między preferencjami ludzi bogatych i ubogich, a nawet ludzi należących do różnych społeczeństw i kręgów kulturowych" [Becker 1990, s. 22].

Omawianie metodologii nowego imperializmu należy zacząć od stwierdzenia, że tak jak stary imperializm w znacznym stopniu opiera się na założeniach ekonomii neoklasycznej, tak nowy wykorzystuje tę samą metodologię, co nowa ekonomia instytucjonalna (NEI). Pod względem metodologicznym NEI nie różni się w stopniu znacznym od ekonomii neoklasycznej. Oznacza to, że nie ma także wielkich różnic pod tym względem pomiędzy starym a nowym imperializmem ekonomii. Oba te nurty opierają się przede wszystkim na metodologicznym indywidualizmie i hipotezie maksymalizacji użyteczności, wykorzystując przy tym formalne, dedukcyjne sposoby myślenia. Mimo to istnieją pewne różnice, które warto tutaj przedstawić.

Główną różnicą jest dostrzeżenie niedoskonałości rynków. Stary imperializm traktował wszystkie sfery życia, ,jak gdyby" były one rynkami i to bardzo często o doskonałej konkurencji. Natomiast nowy imperializm ekonomii traktuje różne zachowania społeczne jako odpowiedź na niedoskonałości rynku. To właśnie poprzez 
pojęcie niedoskonałości rynków są wyjaśniane działania będące uprzednio w obrębie analizy politologii czy socjologii.

Jeszcze większe znaczenie dla rozwoju nowego imperializmu ekonomii miał wspomniany artykuł Akerlofa, który dotyczył informacyjnej niedoskonałości rynków i zapoczątkował rozwój ekonomiki informacji. Zostało w nim pokazane, że nawet małe zmiany w dostępności informacji mogą mieć istotny wpływ na osiągane wyniki ekonomiczne. Rozwój ekonomiki informacji umożliwił wyjaśnienie pewnych instytucji, które w rozumieniu neoklasycznym były zbędne. Ponadto wzrosło znaczenie ograniczenia informacyjnego przy podejmowaniu decyzji, gdyż sama informacja stała się przedmiotem wyboru, co oznacza, że podmiot musi skalkulować, do jakiego poziomu jest dla niego korzystne zdobywać informację, która charakteryzuje się niedarmowością. Z problemem informacji związana jest jej asymetryczność, czego w szczególności dotyczyła praca Akerlofa. Często się zdarza, że pewna grupa posiada przewagę informacyjną nad pozostałymi członkami społeczeństwa. W związku z tym ta uprzywilejowana grupa może dążyć do wykorzystania tej sytuacji, co z kolei związane jest z pokusą nadużycia i negatywną selekcją.

Stiglitz w swoim przemówieniu noblowskim powiedział, że „ekonomika informacji reprezentuje fundamentalną zmianę $\mathrm{w}$ panującym paradygmacie ekonomii. Problem informacji jest kluczowy dla zrozumienia nie tylko rynkowej ekonomii, ale także ekonomii politycznej [...] [pozwoliła ona] odkryć pewne implikacje niedoskonałości informacyjnej dla procesów politycznych" [Fine, Milonakis 2009, s. 65].

Drugą podstawową różnicą jest wykorzystanie przez nowy imperializm ekonomii pojęcia ograniczonej racjonalności - podmiot jest intencjonalnie racjonalny, jednak ze względu na koszty uzyskania informacji, jej asymetrię i inne niedoskonałości rynków nie jest w stanie działać w pełni racjonalnie. Dodatkowo podejmuje on decyzje w pewnym kontekście społeczno-kulturowym, który także zmniejsza jego wolność wyboru. Przyjmuje się również, że mogą zachodzić zmiany w preferencjach.

Podsumowując rozważania dotyczące metodologii nowego i starego imperializmu ekonomii, należy zauważyć, po pierwsze, że nie występują znaczące różnice pomiędzy nimi, a po drugie, że stary imperializm korzysta z podejścia neoklasycznego, natomiast nowy z podejścia prezentowanego przez przedstawicieli nowej ekonomii instytucjonalnej.

\section{Krytyka imperializmu}

Na zakończenie tego artykułu zostanie przedstawiona krytyka „podejścia imperialistycznego" wysunięta przez Rothschilda [2008, s. 729-732]. Pierwszy zarzut tego autora dotyczy dążenia przez przedstawicieli imperializmu ekonomii do czystości teoretycznych podstaw neoklasycznych modeli. Przez pojęcie czystości Rothschild rozumie brak różnorodności metodologicznej w badaniach. Jak zauważa, taka różnorodność jest wymagana przy analizie złożonych zjawisk, nie dających się badać eksperymentalnie i to nie tylko w naukach społecznych, ale także w naukach przy- 
rodniczych, m.in. klimatologii czy meteorologii, gdzie takie podejście przyczyniło się do ich rozwoju.

Drugim bardzo często przedstawianym argumentem jest to, że o ile przy analizie cen i zachowań na konkurencyjnych rynkach jest możliwe zredukowanie człowieka do procesu racjonalnego maksymalizowania, mając dane preferencje i ograniczenia budżetowe, o tyle takie postępowanie nie może się dać łatwo zastosować do pozostałych nauk społecznych, które analizują inne aspekty życia społecznego i związane z nimi działania ludzki. Najbardziej wyrazistym tego przykładem jest psychologia, która stara się wyjaśnić różnice pomiędzy ludźmi, ich motywami i działaniami. Model homo oeconomicus ani żadna z jego modyfikacji nie wydają się, w opinii tego autora, odpowiednie do wyjaśnienia preferencji, a także zmian w nich zachodzących.

Trzecim zarzutem jest nieuwzględnienie kontekstu społecznego. Szczególnie jest to istotne przy analizie zjawisk związanych z socjologią, w których dokonany wybór często nie jest tym, którego dana osoba pożąda, a tym, którego się od niej oczekuje. Zjawisko to jest szczególnie istotne, nawet dzisiaj, przy analizie między innymi małżeństw czy rozrodczości. Zarzut ten odnosi się przede wszystkim do starego imperializmu, gdyż częściowo problem ten jest rozwiązany przez użycie modelu ograniczonej racjonalności w nowym „podejściu imperialistycznym”.

Czwarty argument przeciw imperializmowi ekonomii także dotyczy metodologii i związany jest przede wszystkim z Beckerem. Rothschild zauważa, że o ile łatwo można wymienić czynniki wpływające na dany wybór, o tyle ich zmierzenie i nadanie wartości jest trudne czy wręcz niemożliwe. W związku z tym pojęcie cen cieni pozostaje abstrakcyjnym terminem, a w konsekwencji nie można dokonać porównania różnych wariantów i przeprowadzić procesu racjonalnego wyboru. Dlatego, w opinii tego autora, nie są spełnione, wcześniej wspomniane, przesłanki do unifikacji nauk społecznych w oparciu o ekonomię. Nie można stwierdzić, że na różne zachowania i decyzje ludzi wpływają te same czynniki, a ponadto nowe teorie społeczne oparte na ekonomii nie pozwalają wyjaśnić wszystkich zdarzeń, które są tłumaczone przez zunifikowane teorie.

\section{Zakończenie}

W pracy tej zaprezentowano zjawisko imperializmu ekonomii, czyli ekspansji ekonomii na terytoria okupowane przez inne dyscypliny naukowe i konkurowanie z nimi na tych obszarach. Już w latach 30 . XX wieku zauważono, że podejście ekonomiczne może być przydatne do analizowania zjawisk innych niż gospodarcze. Doprowadziło to do wyjaśnienia zachowań społecznych, związanych m.in. z rodziną, polityką, prawem czy językiem, za pomocą narzędzi i metod charakterystycznych dla ekonomii.

Sam imperializm ekonomii można podzielić na nowy i stary. Jednak jak udowodniono w pracy, podział ten jest przede wszystkim związany z użytą metodologią, a nie czasem jego występowania. Dlatego też wspomnianej freakonomii, powstałej już w XXI wieku, jest dużo bliżej do starego stylu, który używa założeń charakte- 
rystycznych dla nurtu neoklasycznego i którego największym przedstawicielem jest Becker, aniżeli do stylu nowego, który utożsamiany może być z podejściem nowej ekonomii instytucjonalnej, z jej hipotezą ograniczonej racjonalności.

Przeprowadzona w pracy analiza pozwoliła na wyodrębnienie cech charakterystycznych „podejścia imperialistycznego”. Ponadto udało się wyznaczyć główną przyczynę wystąpienia tego zjawiska. Jest nią ideał unifikacji nauki, w omawianym przypadku przejawiający się przez sprowadzenie wszystkich nauk społecznych do ekonomii. Trudniejsza wydaje się ocena tego zjawiska. $\mathrm{Z}$ jednej strony prowadzi ono do unifikacji nauki, co samo w sobie przez wielu naukowców jest uważane za wartościowe, ponieważ potwierdza to poprawność założeń. Pozwala także na dostrzeżenie, wcześniej niezauważonych, prawidłowości w różnych sferach życia społecznego. $Z$ drugiej strony może to nieść, i często niesie, nadmierny redukcjonizm, niezauważanie ważnych czynników i thumaczenie pewnych zjawisk za pomocą stałych założeń, chociaż dane empiryczne temu przeczą.

Pomimo tej niejednoznacznej oceny, w opinii autora, można oczekiwać, że w przyszłości zjawisko imperializmu ekonomii nadal będzie występować. Przyczynić się ono może do dalszego oddalenia się stanowisk przedstawicieli głównego nurtu i szkół heterodoksyjnych. Można także przypuszczać, że w sposób równoważący będzie także rozwijało się zjawisko kooperacji ekonomii z innymi dziedzinami nauki.

\section{Literatura}

Akerlof G.A., The market for "Lemons”: quality uncertainty and the market mechanism, „Quarterly Journal of Economics" 1970, no. 84.

Amadea S.M., Rationalizing Capitalist Democracy: The Cold War Origins of Rational Choice Liberalism, The University of Chicago Press, Chicago - London 2003.

Becker G.S., Ekonomiczna teoria zachowań ludzkich, PWN, Warszawa 1990.

Brunet A., Guichard J.P., Chiny światowym hegemonem? Imperializm ekonomiczny Państwa Środka, Wydawnictwo Studia Emka, Warszawa 2011.

Brzeziński M., Gorynia M., Hockuba Z., Ekonomia a inne nauki społeczne na początku XXI w. Między imperializmem a kooperacja, [w:] B. Fiedor, Z. Hockuba (red.), Nauki ekonomiczne wobec wyzwań wspótczesności, PTE, Warszawa 2009.

Fine B., Economics imperialism and intellectual progress: The present as history of economic thought?, „History of Economics Review” 2000, no. 32.

Fine B., Milonakis D., From Economics Imperialism to Freakonomics: The Shifting Boundaries between Economics and Other Social Sciences, Taylor \& Francis Group, London 2009.

Hirshleifer J., The expanding domain of economics, „American Economic Review Special Issue” 1985, no. 75 .

Hodgson G., How Economics Forgot History: The Problem of Historical Specificity in Social Science, Routledge, London 2001.

Lazear E.P., Economic Imperialism, „Quarterly Journal of Economics” 2000, no. 115.

Levitt S.D., Dubner S.J., Freakonomia: świat od podszewki, Znak, Kraków 2011a.

Levitt S.D., Dubner S.J., Superfreakonomia, Znak, Kraków 2011 b.

Mäki U., Economics Imperialism: Concept and Constraints, 2007 (praca nieopublikowana).

Olson M., Kähkönen S. (eds.), A Not-So-Dismal Science: A Broader View of Economies and Societies, Oxford University Press, Oxford 2000. 
Ostrom E., Challenges and growth: The development of the interdisciplinary field of institutional analysis, ,Journal of Institutional Economics” 2007, vol. 3, no. 3.

Rothschild K.W., Economic Imperialism, Lucius \& Lucius, Stuttgart 2008.

Taylor E., Wstęp do ekonomiki, Wydawnictwo Poznańskiego Towarzystwa Przyjaciół Nauk, Poznań 2004.

\section{ECONOMICS IMPERIALISM}

Summary: In this paper we present the economics imperialism as an attempt to unify social sciences to the theory of economics. We show a lot of definitions of this phenomenon which are proposed in literature, but we point out that to some extent all highlight the issues of crossing of traditional boundaries of economics. Therefore, the definitions often accentuate an aggressive character of this process. In the next step, we present factors which allowed the emergence of the economics imperialism, such as the definition of economics proposed by Robbins, definitions of other social sciences and political factors. However, in the opinion of lot of researchers it was the unification of the science idea, as one of the "purest" goals of the scientific theorizing which was the most important. The influence of the last factor was reinforced also by the failure in finding of microfundaments of macroeconomics, that means internal unification of the economics. Trying to find an evidence of their advantage over heterodox schools, orthodox economists using tools, assumptions and methods which were characterisitc for them, started to analyse different non-market behaviours of people. We also distinguish two criteria of economics imperialism division. The first criterion concerns the subject of research or, in other words, a level of an analysis, so we distinguish the "into" and the "outside" economics imperialism. The aim of the "into" economics imperialism is to depart from traditional economic units and the analysis what these units are composed of and how they function, whereas the "outside" imperialism studies the phenomena of making decisions, which are not directly related to formal markets. The second criterion distinguishes the economics imperialism on the basis of methodologies. The old economics imperialism (the name of which arises from the fact that it was chronologically first, but this type of research is being continued) uses a methodology of the neoclassical economics, with the assumption of stability of preferences or effectiveness and market balance. Thus all areas of life are analysed as if they were markets. The main representative is G.S. Becker, who analyzed law this way. On the other hand the new economics imperialism is related to new institutional economics and its methodological approach. Thus, different behaviours of people are treated as a response to imperfections of markets. The main advocate of this approach is B. Fine. In the last part of the work we show that despite some success of economics imperialism such as finding new correlations or explaining some behaviours, it is criticised. Most of the criticism is related to the lack of satisfying the conditions of reasonable unification of science according to which first, a new, unified theory should explain all problems, which are explained by earlier theories and, second, phenomena which are discussed by this theory should result from the impact of the same real factors on them. Thus, the evaluation of the economics imperialism is not easy, but we can expect that the process of competition between economics and other sciences will be continued.

Keywords: economics imperialism, theory of economics, social science, methodology of economics, unification. 